\title{
Pseudomonas reinekei sp. nov., Pseudomonas moorei sp. nov. and Pseudomonas mohnii sp. nov., novel species capable of degrading chlorosalicylates or isopimaric acid
}

\author{
Beatriz Cámara, ${ }^{1}$ Carsten Strömpl, ${ }^{1}$ Susanne Verbarg, ${ }^{2}$ Cathrin Spröer, ${ }^{2}$ \\ Dietmar H. Pieper ${ }^{1}$ and Brian J. Tindall ${ }^{2}$ \\ ${ }^{1}$ Division of Microbiology, HZI - Helmholtz Zentrum für Infektionsforschung, Inhoffenstrasse 7 \\ 38124 Braunschweig, Germany \\ ${ }^{2} \mathrm{DSMZ}$ - Deutsche Sammlung von Mikroorganismen und Zellkulturen, Inhoffenstrasse 7b, \\ 38124 Braunschweig, Germany
}

Correspondence

Beatriz Cámara

bca@gbf.de

\begin{abstract}
Three bacterial strains, designated $\mathrm{MT} 1^{\top}, \mathrm{RW} 10^{\top}$ and $\mathrm{IpA}-2^{\top}$, had been isolated previously for their ability to degrade chlorosalicylates or isopimaric acid. 16S rRNA gene sequence analysis demonstrated that these bacteria are related to species of the genus Pseudomonas. Analysis of the results of DNA-DNA hybridization with several close phylogenetic neighbours revealed a low level of hybridization (less than $57 \%$ ). On the basis of phenotypic characteristics, phylogenetic analysis, DNA-DNA relatedness data and chemotaxonomic analysis, it is concluded that these isolates represent separate novel species, for which the names Pseudomonas reinekei sp. nov. (type strain $\mathrm{MT}^{\top}{ }^{\top}=\mathrm{DSM} 18361^{\top}=$ CCUG $53116^{\top}$ ), Pseudomonas moorei sp. nov. (type strain RW10 $=\mathrm{DSM} 12647^{\top}=$ CCUG $53114^{\top}$ ) and Pseudomonas mohnii sp. nov. (type strain IpA-2 ${ }^{\top}=\mathrm{DSM}$ $18327^{\top}=$ CCUG $53115^{\top}$ ) are proposed.
\end{abstract}

The genus Pseudomonas sensu lato has been subdivided into several genera following rRNA-DNA hybridization studies (Palleroni et al., 1972, 1973) and 16S rRNA gene sequence comparisons (Anzai et al., 2000; Moore et al., 1996). The species belonging to the genus Pseudomonas sensu stricto are now restricted to rRNA similarity group I of Palleroni (1984), which belongs to the class Gammaproteobacteria (Palleroni, 1984). Polyphasic taxonomic studies and 16S rRNA gene sequence analysis have largely contributed to the stabilization of the taxonomy of Pseudomonas; however, the value of chemotaxonomy (Wilkinson, 1968) in helping to delineate novel taxa is still largely overlooked.

Strains belonging to the genus Pseudomonas are widely distributed in soils and sediments and are well known for having a broad metabolic versatility. Since the first observation of Pseudomonas strains capable of degrading chloroaromatics (Dorn et al., 1974), various other Pseudomonas isolates able to degrade chloroaromatics have been described

\footnotetext{
Abbreviations: LPS, lipopolysaccharide; ME, minimum evolution.

The GenBank/EMBL/DDBJ accession numbers for the 16S rRNA gene sequences of strains $M T 1^{\top}, \mathrm{RW} 10^{\top}$ and $I \mathrm{PA}-2^{\top}$ are respectively AM293565-AM293567, those for the partial atpD gene sequences of strains $M T 1^{\top}, \quad R W 10^{\top}$ and $I \mathrm{PA}-2^{\top}$ are respectively AM293552AM293554 and those for the partial gyrB gene sequences of strains $M T 1^{\top}$, RW $10^{\top}$ and IpA-2 ${ }^{\top}$ are respectively AM293559-AM293561.
}

(Pieper \& Reineke, 2004). As in the case for chloroaromatics, the release of resin acids into the environment has led to considerable environmental concern and, among bacterial isolates able to degrade resin acids, Pseudomonas strains were frequently observed (Martin et al., 1999).

Strain $\mathrm{MT}^{\mathrm{T}}$ is the most abundant organism in a fourmember 4-chlorosalicylate-degrading community isolated from a polluted aerobic sediment of the River Elbe near Bitterfeld, Germany (Pelz et al., 1999). Degradation of 4and 5-chlorosalicylate by $\mathrm{MT}^{\mathrm{T}}$ occurs via 4-chlorocatechol as a central intermediate (Nikodem et al., 2003); however, degradation of 4-chlorocatechol by this strain proceeds by a novel metabolic route distinct from the previously described chlorocatechol pathway and involves a trans-dienelactone hydrolase as a key enzyme. Strain RW $10^{\mathrm{T}}$ was isolated from an enrichment culture inoculated with aerobic sediments from the River Elbe, Hamburg, Germany (Wittich et al., 1999). Like $\mathrm{MT}^{\mathrm{T}}{ }^{\mathrm{T}}, \mathrm{RW} 10^{\mathrm{T}}$ is capable of utilizing 4- or 5chlorosalicylate without involvement of the chlorocatechol pathway, possibly by a metabolic route similar to the one

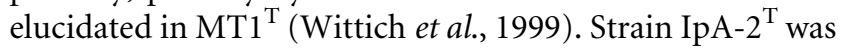
enriched from a laboratory sequencing batch reactor treating pulp mill wastewater (Wilson et al., 1996) on the basis of its ability to degrade the resin acid isopimaric acid, and was characterized previously as a member of Pseudomonas (Mohn et al., 1999). So far, no attempt has been made to 
identify these three organisms to the species level. In the present study, we have undertaken an investigation of the phylogenetic, physiological/biochemical and chemotaxonomic properties of these strains, together with appropriate type strains. Based on the phenotypic and molecular data obtained, three novel species are proposed within the genus Pseudomonas.

As reference strains, Pseudomonas koreensis DSM $16610^{\mathrm{T}}$, Pseudomonas jessenii DSM $17150^{\mathrm{T}}$, Pseudomonas vancouverensis DSM $17555^{\mathrm{T}}$ and Pseudomonas umsongensis DSM $16611^{\mathrm{T}}$ were obtained from the DSMZ. Pseudomonas sp. IpA- $2^{\mathrm{T}}$ was obtained from William Mohn. All strains were cultured in Luria-Bertani (LB) media at $30^{\circ} \mathrm{C}$, unless otherwise indicated. Pseudomonas fluorescens DSM $50090^{\mathrm{T}}$ and Pseudomonas aeruginosa DSM 50071 ${ }^{\mathrm{T}}$ were used for comparative purposes in the chemotaxonomic studies.

\section{$16 S$ rRNA, atpD and gyrB gene sequence analysis and DNA-DNA hybridization}

Genomic DNA was prepared from single colonies which were suspended in $100 \mu \mathrm{l} \mathrm{TE}$ buffer, heated to $95^{\circ} \mathrm{C}$ for $5 \mathrm{~min}$ and centrifuged briefly; the supernatant was used. $16 \mathrm{~S}$ rRNA gene amplification and sequencing was carried out as described previously (Moore et al., 1996).

For atpD amplification, previously designed primers (Hilario et al., 2004) were modified based on an upgraded alignment of recently published Pseudomonas atpD gene sequences to give primers atpD-F ( $5^{\prime}$-CTGGGCCGBATCATGGACG-3') and atp-R (5'-GTCCATRCCCAGGATSGC$3^{\prime}$ ). PCR amplifications [ $50 \mu \mathrm{l}$ final volume: $20 \mathrm{pmol}$ of each primer, $5 \mathrm{nmol}$ dNTPs (Peqlab), $2.5 \mathrm{U}$ Taq polymerase (Qiagen) and $1 \mu$ DNA template] were performed on an AB9700 thermal cycler (Applied Biosystems) with an initial denaturation at $94{ }^{\circ} \mathrm{C}$ for $2 \mathrm{~min}, 35$ cycles of denaturation $\left(94{ }^{\circ} \mathrm{C}, 30 \mathrm{~s}\right)$, annealing $\left(58^{\circ} \mathrm{C}, 45 \mathrm{~s}\right)$ and elongation $\left(72^{\circ} \mathrm{C}\right.$, $60 \mathrm{~s}$ ) and a final elongation at $72^{\circ} \mathrm{C}$ for $5 \mathrm{~min}$. gyrB gene amplifications (approx. 900 bp fragment) were performed as indicated above but with $10 \mathrm{pmol}$ of each primer (Yamamoto et al., 2000). PCR conditions included an initial denaturation at $96^{\circ} \mathrm{C}$ for 2 min followed by 5 cycles of denaturation $\left(95^{\circ} \mathrm{C}, 30 \mathrm{~s}\right)$, annealing $\left(62^{\circ} \mathrm{C}, 60 \mathrm{~s}\right)$ and elongation $\left(72^{\circ} \mathrm{C}, 60 \mathrm{~s}\right), 30$ further cycles as before but with annealing at $57^{\circ} \mathrm{C}$ for $45 \mathrm{~s}$ and a final elongation at $72^{\circ} \mathrm{C}$ for $5 \mathrm{~min}$. Purified amplicons were sequenced using the PCR primers described above. Reactions contained $10 \mathrm{pmol}$ primer, $2 \mu$ B BigDye 1.1 premix (Applied Biosystems), $1 \mu \mathrm{l}$ buffer and approx. $10 \mathrm{ng}$ DNA in a $10 \mu \mathrm{l}$ reaction. Cycle sequencing was carried out at the appropriate annealing temperatures for 25 cycles. DNA sequences were resolved on a 3130xl DNA sequencer (Applied Biosystems). Sequences were edited and assembled with Sequencher software (Gene Codes Co.) and consensus sequences were aligned using CLUSTAL X (Thompson et al., 1997). Alignments were imported and edited manually in MEGA3 software (Kumar et al., 2004), bootstrap analysis was performed by 1000 resamplings and graphical representations of the data were calculated using Jukes-Cantor distances.

PCR amplification and cycle sequencing of atpD and $\operatorname{gyr} B$ genes yielded PCR products of the expected length and without any ambiguous nucleotide positions. In contrast, the $16 \mathrm{~S}$ rRNA gene sequences of strains RW $10^{\mathrm{T}}$ and IpA- $2^{\mathrm{T}}$ included ambiguous nucleotides at several positions situated in helix $18\left(\mathrm{RW} 10^{\mathrm{T}}\right.$ and $\left.\mathrm{IpA}-2^{\mathrm{T}}\right)$ and helix $37\left(\mathrm{RW} 10^{\mathrm{T}}\right)$, indicating sequence heterogeneities. It is unlikely that these heterogeneities were due to contamination, but were rather the effect of the presence of multiple heterogeneous $16 \mathrm{~S}$ rRNA operons, an anomaly also reported for a variety of bacterial taxa including other Pseudomonas species (Nelson et al., 2002).

$16 \mathrm{~S}$ rRNA gene sequence dissimilarities were calculated from 1426 nucleotide positions. In the sequences of strains IpA- $2^{\mathrm{T}}$ and $\mathrm{RW}-10^{\mathrm{T}}$, there were 8 and 18 ambiguous positions, which might be due to heterogeneities between multiple operons (Coenye \& Vandamme, 2003). These positions overlapped and were found in regions of the $16 \mathrm{~S}$ rRNA gene sequence which showed the greatest degree of variability. These differences might reflect real differences between the different operons within a single strain, but their resolution would not necessarily contribute to solving the taxonomic question addressed in this paper. Given the high degree of similarity between the strains used in this study, the resolution of the 16S rRNA gene sequences is not sufficient to allow delineation of the various species, and the circumscription of the novel species depends primarily on data other than the 16S rRNA gene sequence. Removing the stretch of 18 nucleotides from the analysis did not affect the position of this group of strains relative to other Pseudomonas species. The group of strains studied here formed a distinct cluster within the genus Pseudomonas (Kwon et al., 2003), sharing $>98 \%$ sequence similarity within the cluster, but $<97 \%$ sequence similarity to other species within the genus Pseudomonas. Because of the removal of the 18 polymorphic positions, these values are fairly conservative. In addition to the 16S rRNA gene sequence data, there are indications of heterogeneity within the genus Pseudomonas, such as differences in chemotaxonomic properties (Stead, 1992; Vancanneyt et al., 1996), which we have used to reduce the number of species included in this taxonomic study. As a consequence, sequence distances between strains $\mathrm{MT}^{\mathrm{T}}$, IpA- $2^{\mathrm{T}}$ and $\mathrm{RW} 10^{\mathrm{T}}$ and the type strains of $P$. umsongensis, $P$. vancouverensis, $P$. koreensis and $P$. jessenii were $<0.01$ (i.e. $1 \%$ sequence divergence; Fig. 1a) and thus could not be used to identify interspecific relationships between related taxa.

In order to achieve greater interspecific resolution at the genus level, two housekeeping genes, atpD (Hilario et al., 2004) and gyrB (Yamamoto et al., 2000), were sequenced. Analysis of approximately 775 nucleotides of the atpD genes revealed that strain $\mathrm{MT}^{\mathrm{T}}$ had the highest degree of similarity to the type strains of $P$. jessenii $(99.1 \%)$ and $P$. koreensis (98.7\%) (Fig. 1b). The translated AtpD amino 
(a)

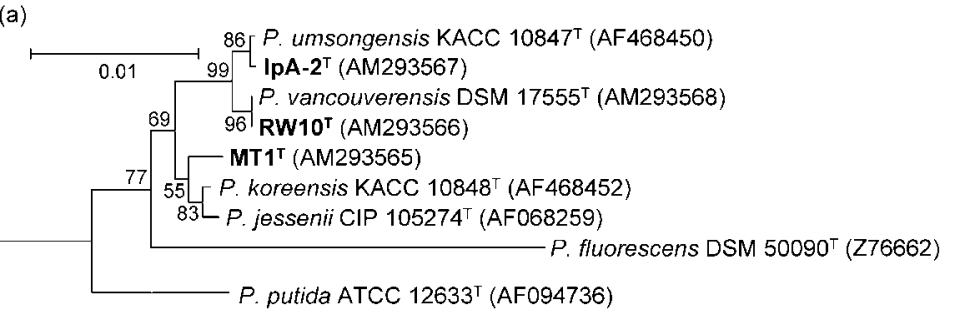

P. aeruginosa ATCC $10145^{\top}$ (AF094713)
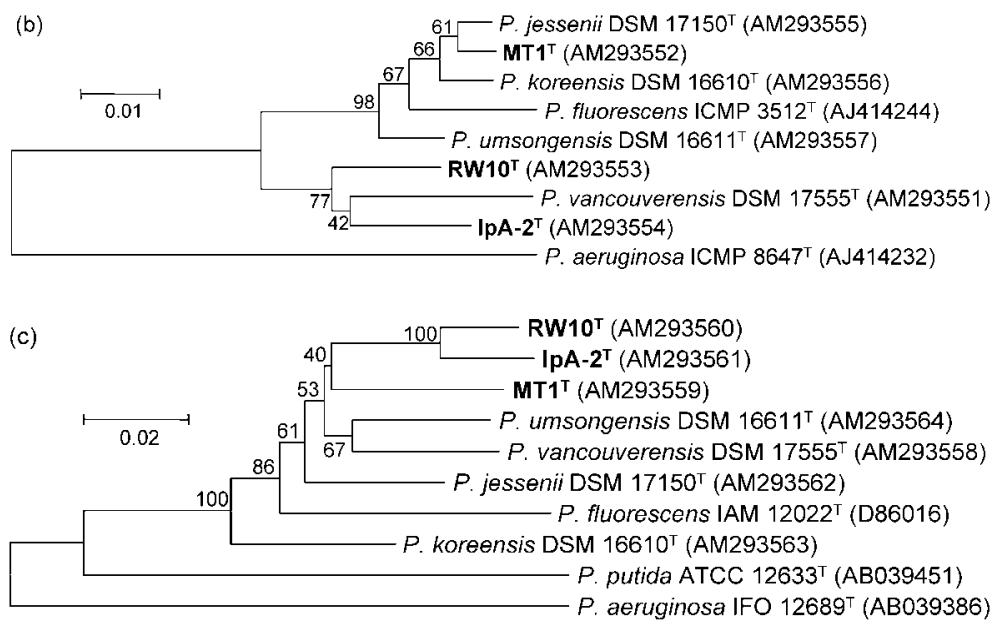

Fig. 1. Similarity dendrograms based on comparison of nearly complete $16 \mathrm{~S}$ rRNA gene sequences (a), partial atp $D$ gene sequences (b) and partial gyrB gene sequences (c). The dendrograms were calculated with the ME method (Nei \& Kumar, 2000) after distance correction as described by Jukes \& Cantor (1969) and as implemented in the MEGA3 software package (Kumar et al., 2004). Reliability of the inferred trees was tested by bootstrapping using 1000 resamplings. Only columns in which all nucleotides were determined unambiguously were included in the calculation. The atp $D$ sequence of the type strain of Pseudomonas putida was not available from public databases. Bars, 1 estimated substitution per 100 bases. acid sequences of these three strains were identical, indicating that the changes in the nucleotide sequences were the result of synonymous substitutions. Strains $\mathrm{IpA}-2^{\mathrm{T}}$ and RW $10^{\mathrm{T}}$ differed from each other $(2.8 \%$ sequence dissimilarity) and from strain $\mathrm{MT}^{\mathrm{T}}$ (5.8 and $5.1 \%$ sequence dissimilarity, respectively) and, according to their atpD sequences, were most closely related to $P$. vancouverensis DSM $17555^{\mathrm{T}}$ (3.8 and $4.2 \%$ sequence dissimilarity, respectively), a strain reported previously to be able to degrade the resin acid dehydroabietic acid (Mohn et al., 1999).

Dissimilarities of partial gyrB gene sequences deduced from comparison of 890 nucleotide sites revealed greater sequence dissimilarities than observed for the 16S rRNA and atpD gene sequences (Fig. 1c). The sequence dissimilarity between strains IpA-2 $2^{\mathrm{T}}$ and $\mathrm{RW} 10^{\mathrm{T}}$ was found to be $3.3 \%$, and the distances to strain $\mathrm{MT}^{\mathrm{T}}$ were 7.4 and $6.7 \%$, respectively.

The overall tree topology derived from the minimumevolution (ME; Kumar et al., 2004) dendrogram of the $16 \mathrm{~S}$ rRNA gene sequences was consistent with maximumparsimony and neighbour-joining trees and did not change when different distance models were chosen for calculation in the latter method of analysis. As shown in Fig. 1(b), the clustering of the atpD gene sequences of the three strains was similar to that observed from the $16 \mathrm{~S}$ rRNA gene sequence dendrogram. In all cases, strains IpA- $2^{\mathrm{T}}$ and RW $10^{\mathrm{T}}$ clustered with $P$. vancouverensis DSM $17555^{\mathrm{T}}$ and strain $\mathrm{MT}^{\mathrm{T}}$ clustered with $P$. jessenii DSM $17150^{\mathrm{T}}$ and $P$. koreensis DSM $16610^{\mathrm{T}}$. Whilst the AtpD dendrograms derived from translated amino acid sequences exhibited very short internal branches, which resulted in changes in the internal branching order (data not shown), the overall clustering remained constant.

The tree topology of the $g y r B$ nucleotide sequence-derived dendrograms differed slightly depending on the method of calculation used. It was, however, consistent for the trees constructed from translated amino acid sequences, despite weak statistical support as expressed by low bootstrap values. Comparison of the aligned nucleic acid and translated amino acid sequences revealed that, similar to atpD, most nucleotide exchanges were synonymous, resulting in highly similar amino acid sequences (data not shown).

Several attempts have been made to resolve the intrageneric structure of the genus Pseudomonas by analyses of the sequences of the 16S rRNA gene (Anzai et al., 2000; Moore et al., 1996) and protein-coding genes (Ait Tayeb et al., 2005; Hilario et al., 2004; Yamamoto \& Harayama, 1995; Yamamoto et al., 2000). These studies revealed that defined clusters exist within the genus. However, as observed in this study (Fig. 1), tree topologies were incongruent and poorly supported at a statistical level. Nevertheless, nucleotide sequence distances of $g y r B$ and atpD allowed differentiation of the three strains from closely related species.

A good correlation between gyrB sequence dendrograms and DNA-DNA association data for the genus Acinetobacter was 
reported (Yamamoto et al., 1999). The authors reported an estimated species limit of 0.041 sequence distance for $\mathrm{g} y \mathrm{rB}$, corresponding to a DNA-DNA hybridization value of $>70 \%$ for species within this genus. In the present study, DNA for DNA-DNA hybridization studies was isolated by using a French pressure cell and purified by chromatography on hydroxyapatite (Cashion et al., 1977). DNA-DNA reassociation was performed under optimal conditions $\left(2 \times\right.$ SSC plus $5 \%$ formamide at $\left.70{ }^{\circ} \mathrm{C}\right)$ and recorded using a Gilford 2600 spectrophotometer. With the exception of the pair IpA-2 ${ }^{\mathrm{T}}$ and $\mathrm{RW} 10^{\mathrm{T}}$ (distance 0.033 ), all distances found for the sequence set used in the dendrograms (Fig. 1c) were $>0.05$; however, the DNA-DNA hybridization value for IpA- $2^{\mathrm{T}}$ and $\mathrm{RW} 10^{\mathrm{T}}$ was only $50.2 \%$ (53.4\% reciprocal value; Table 1 ).

DNA-DNA hybridization was carried out with closely related type strains, which were selected on the basis of their $16 \mathrm{~S}$ rRNA gene sequence similarities. The three novel strains shared the highest DNA relatedness (45-56\%) among the species compared, none of which gave a value for DNADNA relatedness higher than the $70 \%$ guideline value (Wayne et al., 1991).

\section{Chemotaxonomy}

Respiratory lipoquinones and polar lipids were extracted from freeze-dried cell material (100 mg) using a two-stage method (Tindall, 1990a, b). Lipoquinones were separated by TLC and UV-absorbing bands were removed from the plate and analysed further by reverse-phase HPLC. Polar lipids were separated by two-dimensional, silica-gel TLC; total lipid material and specific functional groups were detected using dodecamolybdophosphoric acid (total lipids), Zinzadze reagent (phosphate), ninhydrin (free amino groups), periodate-Schiff ( $\alpha$-glycols), Dragendorff (quaternary nitrogen) and anisaldehyde-sulfuric acid (glycolipids) as described previously (Tindall, 1990a, b). Fatty acids were analysed as the methyl ester derivatives prepared from $10 \mathrm{mg}$ dry cell material. Cells were subjected to differential hydrolysis to detect ester-linked and non-ester-linked

Table 1. Results of DNA-DNA hybridization experiments

Values are percentage results from hybridization at $70^{\circ} \mathrm{C}$. Reciprocal values are given in parentheses. ND, Not done.

\begin{tabular}{|c|c|c|c|}
\hline Strain & $\mathrm{MT1}^{\mathrm{T}}$ & RW10 ${ }^{\mathrm{T}}$ & IpA-2 ${ }^{T}$ \\
\hline P. koreensis DSM $16610^{\mathrm{T}}$ & $35.1(41.5)$ & $39.5(33.6)$ & ND \\
\hline $\begin{array}{l}\text { P. vancouverensis DSM } \\
17555^{\mathrm{T}}\end{array}$ & $28.9(29.3)$ & $15.1(8.2)$ & $30.7(37.1)$ \\
\hline $\begin{array}{l}\text { P. umsongensis DSM } \\
16611^{\mathrm{T}}\end{array}$ & $22.4(34.5)$ & $40.5(42.6)$ & $23.3(29.9)$ \\
\hline P. jessenii DSM $17150^{\mathrm{T}}$ & $44.8(49.2)$ & $56.4(55.7)$ & ND \\
\hline Strain $\mathrm{RW} 10^{\mathrm{T}}$ & $33.4(41.2)$ & - & $50.2(53.4)$ \\
\hline Strain $\mathrm{MT}^{\mathrm{T}}$ & - & $33.4(41.2)$ & ND \\
\hline
\end{tabular}

(amide-bound) fatty acids (Labrenz et al., 1998). Fatty acid methyl esters were analysed by GC using a $0.2 \mu \mathrm{m} \times$ $25 \mathrm{~m}$ non-polar capillary column and flame-ionization detection under conditions as follows: injection and detector port temperature, $300^{\circ} \mathrm{C}$; inlet pressure, $60 \mathrm{kPa}$; split ratio, $50: 1$; injection volume, $1 \mu \mathrm{l}$; temperature program, $130-310^{\circ} \mathrm{C}$ at a rate of $4{ }^{\circ} \mathrm{C} \min ^{-1}$.

All strains produced ubiquinones, with ubiquinone 9 (Q9) as the predominant respiratory lipoquinone. The fatty acid compositions (Table 2) are consistent with those published previously for members of the genus Pseudomonas (Pseudomonas RNA group 1) (Stead, 1992; Vancanneyt et al., 1996). However, additional observations could be made which are relevant to any future evaluation of the taxonomy of this genus. All strains contained saturated and unsaturated $\mathrm{C}_{16}$ and $\mathrm{C}_{18}$ fatty acids as the main components, although this is not particularly unusual for members of the Gammaproteobacteria. Discrimination lies at the level of the 'lessimportant' fatty acids, some of which are probably components of the lipopolysaccharides (LPS), rather than being present in the polar lipids. This is particularly true of the $2-\mathrm{OH}$ and $3-\mathrm{OH}$ fatty acids, where the exact structure of the LPS from $P$. aeruginosa strains has been described (Ernst et al., 1999). The differential hydrolysis methods used here indicated that the 3-OH 10:0 and 2-OH 12:0 fatty acids are ester-linked, while the $3-\mathrm{OH} 12: 0$ fatty acid appears to be amide- and/or ester-linked, depending on the strain examined. With the exception of strain $\mathrm{RW} 10^{\mathrm{T}}$, the (genetically) closely related group of strains examined contained only amide-linked 3-OH 12:0. In contrast, both $P$. aeruginosa DSM $50071^{\mathrm{T}}$ and P. fluorescens DSM $50090^{\mathrm{T}}$ contained both amide- and ester-linked 3-OH 12:0. These results are the first indication that such methods might help to differentiate groups within 'Pseudomonas RNA group 1'. It is interesting to note that all closely related strains examined here produced 12:0 fatty acids (up to $6 \%$ of the total fatty acid composition) and that $14: 0$ fatty acids were present in relatively small amounts $(<1.0 \%$ of total fatty acid composition). The presence of $2-\mathrm{OH} 12: 0$ fatty acids in all strains examined is characteristic for the majority of species within the genus Pseudomonas (Vancanneyt et al., 1996). Strains that produce more than trace amounts ( $>1 \%$ ) of $14: 0$ fatty acids are clearly definable (Vancanneyt et al., 1996) and also group together based on the combined analysis of the nucleotide sequences of the gyrB and $r p o D$ genes (Yamamoto et al., 2000) as a distinct subgroup that is included in intrageneric cluster I within the genus Pseudomonas, as well as on the basis of 16S rRNA gene sequence data (Moore et al., 1996). In the strains studied here, only trace amounts of 14:0 fatty acids were detected, confirming that the strains belong in the intrageneric cluster II defined previously (Yamamoto et al., 2000). It is interesting to notice that the different levels of $12: 0$ in the small number of taxa examined here indicate that this fatty acid might also be useful to help detect infrastructure within the genus Pseudomonas. Clearly there is more scope for the evaluation of intrageneric groupings within the genus Pseudomonas (RNA 


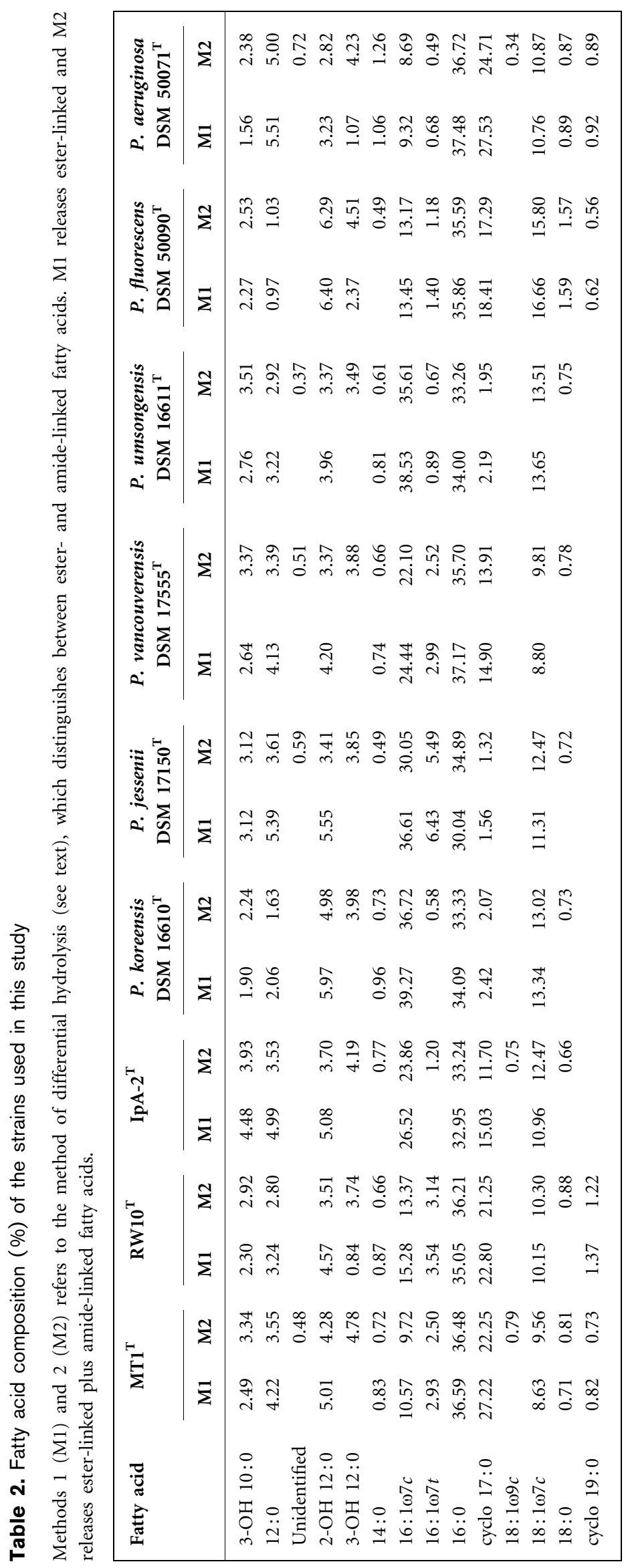

group I of Palleroni) (Palleroni et al., 1972, 1973) based on both genetic and epigenetic datasets.

The polar lipids were characterized by the presence of three major phospholipids, phosphatidylglycerol, diphosphatidylglycerol and phosphatidylethanolamine (Fig. 2). In the case of $P$. aeruginosa DSM $50071^{\mathrm{T}}$, we were unable to detect any significant amounts of phosphatidylcholine unambiguously, although genes encoding its biosynthesis have been reported in a strain of this species (Sohlenkamp et al., 2003). Biosynthesis might be dependent on an external source of choline.

Based on the data collected here, it seems that, even though the different species are not characterized by individual fatty acid or polar lipid patterns, typical patterns might be observed at the level of 'groups of species'. Given the relatively large $16 \mathrm{~S}$ rRNA gene sequence divergences between members of the genus Pseudomonas (Moore et al., 1996), it is possible that the infrastructure indicated in this and previous work (Stead, 1992; Vancanneyt et al., 1996) might correlate with groups of species within this genus. Clearly, more detailed studies on the role of fatty acid distribution in the LPS would appear to be a line of investigation that might be profitable. These groups might also correlate, in turn, with other features, such as the distribution of certain biochemical pathways.

Based on the results presented here, we conclude that strains $M T 1^{\mathrm{T}}, \mathrm{IpA}-2^{\mathrm{T}}$ and $\mathrm{RW} 10^{\mathrm{T}}$ represent novel species of the genus Pseudomonas within the Gammaproteobacteria.

\section{Physiological and biochemical characteristics}

Lecithinase and hydrolysis of Tween 80 (Gerhardt et al., 1994) and levan formation (Cowan \& Steel, 1974) were determined as previously described. Fluorescent pigment production was tested on Pseudomonas B agar (King et al., 1954). Salinity tolerance was analysed by growth on trypticase soy broth supplemented with 5 and $7 \% \mathrm{NaCl}$. Temperature tolerance was tested by determining growth at $41^{\circ} \mathrm{C}$.

Physiological and biochemical tests were performed on all seven strains at $28^{\circ} \mathrm{C}$ using API 20NE strips and Biolog GN2 microplates, according to the manufacturers' instructions. All tests were inoculated with cells pre-grown on trypticase soy yeast extract agar (per litre distilled water: $30.0 \mathrm{~g}$ trypticase soy broth, $3.0 \mathrm{~g}$ yeast extract, $15 \mathrm{~g}$ agar). API 20NE strips were examined after $48 \mathrm{~h}$ and Biolog GN2 plates were observed after 25 and $48 \mathrm{~h}$ of incubation.

Differential physiological and biochemical characteristics of the novel strains and related Pseudomonas species are summarized in Table $3 . \mathrm{MT}^{\mathrm{T}}$ is the only strain that has the ability to form levan, and it differs from RW $10^{\mathrm{T}}$ and IpA- $2^{\mathrm{T}}$ in the absence of arginine dihydrolase. Strains RW $10^{\mathrm{T}}$ and IpA- $2^{\mathrm{T}}$ can not be differentiated by the characteristics specified in Table 3, which is reflected in the elevated value in DNA-DNA relatedness (Table 1), as well as by the 

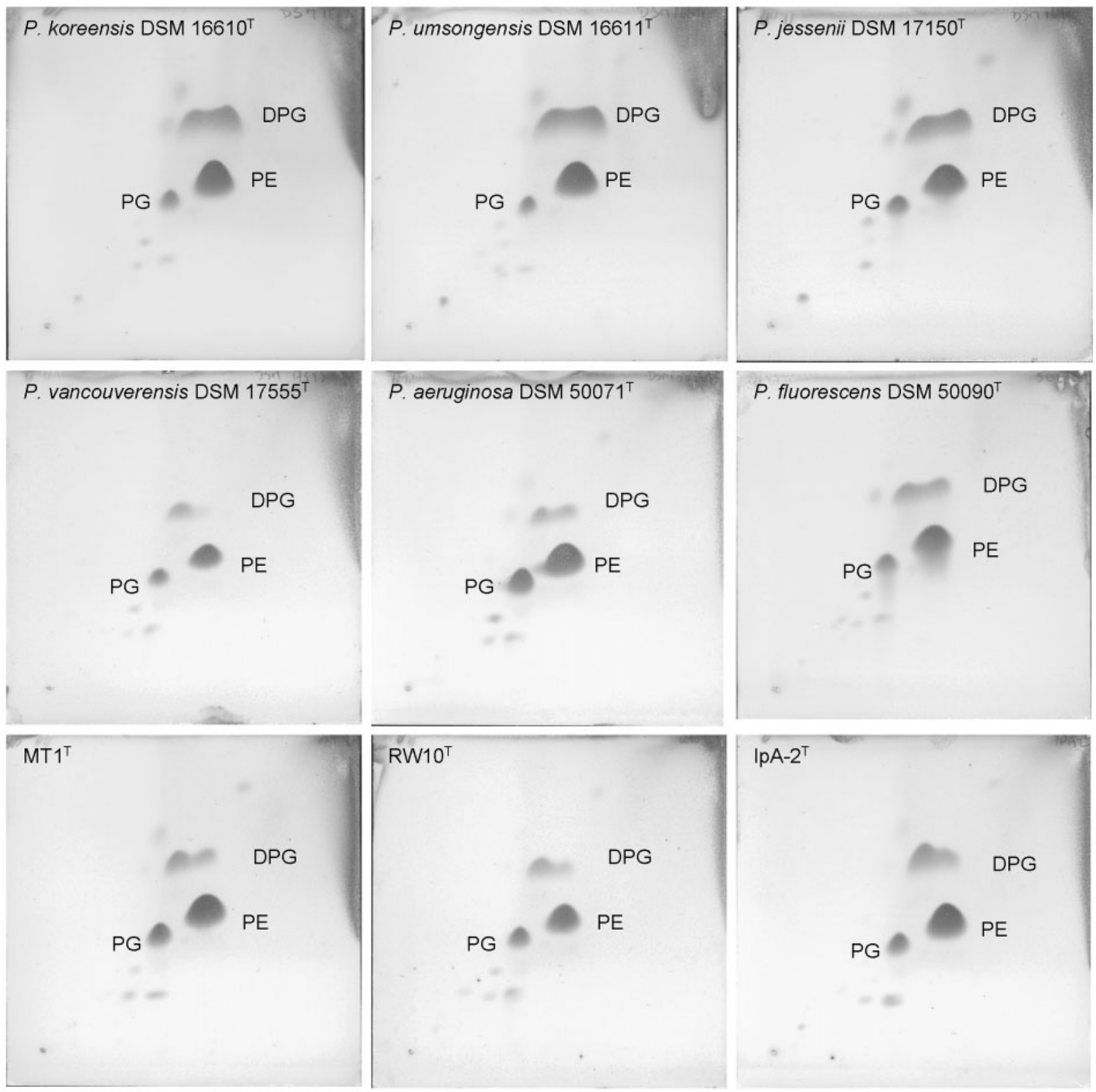

Fig. 2. Polar lipid profiles of strains $M T 1^{\top}, R W 10^{\top}$ and $I p A-2^{\top}$ and six reference strains after separation by two-dimensional TLC. DPG, Diphosphatidylglycerol; PE, phosphatidylethanolamine; PG, phosphatidylglycerol.

similarity depicted in the phylogenetic trees (Fig. 1). However, a detailed analysis of carbon source dissimilation capabilities by the Biolog system (Table 4) revealed that strain $\mathrm{RW} 10^{\mathrm{T}}$ differed from $\mathrm{IpA}-2^{\mathrm{T}}$ in its ability to dissimilate L-histidine and L-pyroglutamic acid.

\section{Description of Pseudomonas reinekei sp. nov.}

Pseudomonas reinekei (rei'ne.ke.i. N.L. gen. n. reinekei of/ from Reineke, named in honour of Walter Reineke, for his pioneering contributions to the study of the biodegradation of chlorinated aromatics).
Cells are Gram-negative and non-spore-forming. Colonies are circular, white-yellow and mucoid on LB agar and become mucoid after 2 days of incubation. No fluorescent pigments are produced on King's B medium. Cells are oxidase-positive and are able to form levan, but show no hydrolysis of arginine, hydrolysis of Tween 80 or reduction of nitrate. Lecithinase, urease and $\beta$-galactosidase reactions are negative and there is no hydrolysis of aesculin or gelatin. Indole is not produced from tryptophan and there is no glucose fermentation. Growth does not occur at $41{ }^{\circ} \mathrm{C}$ or in media supplemented with 5 or $7 \% \mathrm{NaCl}$. Results obtained with Biolog GN2 microplates indicate that the following 
Table 3. Characteristics that differentiate strains $\mathrm{MT}^{\top}$, RW $10^{T}$ and IpA $-2^{T}$ from other closely related Pseudomonas species

Strains: $1, \mathrm{MT1}^{\mathrm{T}} ; 2, \mathrm{RW} 10^{\mathrm{T}} ; 3, \mathrm{IpA}-2^{\mathrm{T}} ; 4, P$. koreensis DSM $16610^{\mathrm{T}} ; 5, P$. jessenii DSM $17150^{\mathrm{T}} ; 6, P$. vancouverensis DSM $17555^{\mathrm{T}} ; 7$, P. umsongensis DSM $16611^{\mathrm{T}}$.

\begin{tabular}{|lccccccc|}
\hline Characteristic & $\mathbf{1}$ & $\mathbf{2}$ & $\mathbf{3}$ & $\mathbf{4}$ & $\mathbf{5}$ & $\mathbf{6}$ & $\mathbf{7}$ \\
\hline Fluorescence & - & - & - & + & + & + & + \\
Formation of levan & + & - & - & - & - & - & - \\
Hydrolysis of Tween 80 & - & - & - & + & - & - & - \\
Growth in the presence of $5 \%$ & - & - & - & + & - & - & - \\
NaCl & & & & & & & \\
Reduction of nitrate & - & - & - & - & + & + & + \\
Presence of arginine dihydrolase & - & + & + & + & - & - & + \\
Assimilation of: & & & & & & & \\
$\quad$ Arabinose & + & + & + & + & + & - & + \\
$\quad$ Mannitol & + & + & + & + & + & + & - \\
$\quad N$-Acetylglucosamine & - & - & - & + & + & + & - \\
$\quad$ Phenylacetic acid & + & + & + & - & + & + & + \\
& & & & & & &
\end{tabular}

substrates are utilized: L-arabinose, D-arabitol, D-galactose, $\alpha$-D-glucose, methyl pyruvate, monomethyl succinate, acetic acid, cis-aconitic acid, citric acid, formic acid, D-galactonic acid lactone, D-galacturonic acid, D-gluconic acid, $\beta$ hydroxybutyric acid, $\alpha$-ketoglutaric acid, DL-lactic acid, quinic acid, D-saccharic acid, succinic acid, bromosuccinic acid, L-asparagine, L-aspartic acid, L-glutamic acid, L-proline, L-pyroglutamic acid, urocanic acid, phenylethylamine and glycerol. Weak utilization is observed of D-glucosaminic acid, $\alpha$-hydroxybutyric acid, malonic acid, propionic acid, alaninamide, L-alanine, L-serine, DL-carnitine and 2-aminoethanol. The other organic substrates included in the Biolog GN2 microplates are not utilized. Consistent with the chemical properties of the genus, the major respiratory lipoquinone present is ubiquinone 9 (Q9) and the major phospholipids are phosphatidylglycerol, diphosphatidylglycerol and phosphatidylethanolamine. The fatty acids present include $3-\mathrm{OH} 10: 0,12: 0,2-\mathrm{OH} 12: 0,3-\mathrm{OH} 12: 0,14: 0$, $16: 1 \omega 7 c, 16: 1 \omega 7 t, 16: 0$, cyclo $17: 0,18: 1 \omega 9 c, 18: 1 \omega 7 c$, 18:0 and cyclo 19:0. The level of $14: 0$ does not exceed $1.5 \%$. The 3-OH 10:0 and 2-OH 12:0 are ester-linked, while the $3-\mathrm{OH} 12: 0$ is amide-linked.

The type strain is $\mathrm{MT}^{\mathrm{T}}\left(=\mathrm{DSM} 18361^{\mathrm{T}}=\mathrm{CCUG} 53116^{\mathrm{T}}\right)$.

\section{Description of Pseudomonas moorei sp. nov.}

Pseudomonas moorei (moo're.i. N.L. gen. n. moorei of/from Moore, named in honour of Edward R. B. Moore, for his important contributions to the study of the genus Pseudomonas).

Cells are Gram-negative and non-spore-forming. Colonies are circular and white-yellow on LB agar. Cells do not produce a fluorescent pigment on King's B medium. Cells are oxidase-positive and show hydrolysis of arginine, but do not reduce nitrates or hydrolyse Tween 80 . Does not show
Table 4. Differences in carbon source dissimilation according to Biolog GN2 for Pseudomonas type strains

Strains: $1, \mathrm{MT}^{\mathrm{T}} ; 2, \mathrm{RW} 10^{\mathrm{T}} ; 3, \mathrm{IpA}-2^{\mathrm{T}} ; 4$, P. koreensis DSM $16610^{\mathrm{T}} ; 5, P$. jessenii DSM $17150^{\mathrm{T}} ; 6, P$. vancouverensis DSM $17555^{\mathrm{T}} ; 7, \quad$. umsongensis DSM $16611^{\mathrm{T}}$. b, Borderline (values between 20 and $25 \%$ of the highest reaction value after $25 \mathrm{~h}$ of incubation).

\begin{tabular}{|c|c|c|c|c|c|c|c|}
\hline Carbon source & 1 & 2 & 3 & 4 & 5 & 6 & 7 \\
\hline Dextrin & - & - & - & - & - & - & $\mathrm{b}$ \\
\hline Tween 40 & - & - & - & - & + & - & $\mathrm{b}$ \\
\hline Tween 80 & - & - & - & - & + & $\mathrm{b}$ & + \\
\hline $\mathrm{N}$-Acetyl-D-glucosamine & - & - & - & + & + & + & - \\
\hline L-Arabinose & + & + & + & + & + & - & + \\
\hline D-Arabitol & + & - & - & + & - & - & - \\
\hline D-Fructose & - & - & - & + & + & $\mathrm{b}$ & + \\
\hline D-Galactose & + & + & + & + & + & - & - \\
\hline D-Mannitol & - & + & + & + & + & + & - \\
\hline D-Mannose & - & - & $\mathrm{b}$ & + & + & - & - \\
\hline Methyl pyruvate & + & + & + & $\mathrm{b}$ & + & + & $\mathrm{b}$ \\
\hline Monomethyl succinate & + & + & $\mathrm{b}$ & + & + & + & $\mathrm{b}$ \\
\hline Acetic acid & + & - & - & - & + & + & + \\
\hline Formic acid & + & - & $\mathrm{b}$ & - & + & - & - \\
\hline D-Galactonic acid lactone & + & + & + & + & + & - & + \\
\hline D-Galacturonic acid & + & + & + & - & - & - & + \\
\hline D-Glucosaminic acid & $\mathrm{b}$ & + & $\mathrm{b}$ & + & - & + & - \\
\hline D-Glucuronic acid & - & + & + & - & - & - & + \\
\hline$\alpha$-Hydroxybutyric acid & $\mathrm{b}$ & - & - & - & - & - & - \\
\hline p-Hydroxyphenylacetic acid & - & - & - & - & + & - & - \\
\hline$\alpha$-Ketoglutaric acid & + & + & + & + & + & + & - \\
\hline Malonic acid & $\mathrm{b}$ & - & $\mathrm{b}$ & + & + & + & $\mathrm{b}$ \\
\hline Propionic acid & $\mathrm{b}$ & - & $\mathrm{b}$ & + & + & + & + \\
\hline Quinic acid & + & + & + & + & + & - & + \\
\hline D-Saccharic acid & + & + & + & + & + & - & + \\
\hline Succinamic acid & - & - & - & - & - & + & - \\
\hline Glucuronamide & - & - & - & - & - & - & + \\
\hline Alaninamide & $\mathrm{b}$ & - & - & - & + & $\mathrm{b}$ & - \\
\hline D-Alanine & - & $\mathrm{b}$ & + & + & + & + & + \\
\hline L-Alanine & $\mathrm{b}$ & $\mathrm{b}$ & + & + & + & + & $\mathrm{b}$ \\
\hline L-Alanyl glycine & - & - & - & $\mathrm{b}$ & + & - & - \\
\hline L-Histidine & - & + & - & - & + & - & + \\
\hline Hydroxy-L-proline & - & + & + & + & + & + & + \\
\hline L-Leucine & - & - & - & - & + & - & $\mathrm{b}$ \\
\hline L-Ornithine & - & - & - & - & + & + & - \\
\hline L-Phenylalanine & - & - & - & - & - & $\mathrm{b}$ & - \\
\hline L-Pyroglutamic acid & + & + & - & + & + & - & + \\
\hline D-Serine & - & - & - & - & + & - & - \\
\hline L-Serine & $\mathrm{b}$ & + & + & + & + & + & + \\
\hline L-Threonine & - & - & - & - & + & - & - \\
\hline DL-Carnitine & $\mathrm{b}$ & $\mathrm{b}$ & + & + & $\mathrm{b}$ & + & $\mathrm{b}$ \\
\hline$\gamma$-Aminobutyric acid & - & + & + & + & + & + & - \\
\hline Inosine & - & - & - & + & - & $\mathrm{b}$ & - \\
\hline Uridine & - & - & - & + & - & - & - \\
\hline Phenylethylamine & + & - & $\mathrm{b}$ & - & + & $\mathrm{b}$ & + \\
\hline Putrescine & - & $\mathrm{b}$ & $\mathrm{b}$ & + & + & + & + \\
\hline 2-Aminoethanol & $\mathrm{b}$ & $\mathrm{b}$ & - & + & + & - & - \\
\hline DL- $\alpha$-Glycerol phosphate & - & - & - & $\mathrm{b}$ & + & - & - \\
\hline
\end{tabular}


lecithinase, urease or $\beta$-galactosidase reactions or hydrolysis of aesculin or gelatin. Indole is not produced on tryptophan and there is no glucose fermentation. Does not grow at $41{ }^{\circ} \mathrm{C}$ or in media supplemented with 5 or $7 \% \mathrm{NaCl}$. Results obtained with Biolog GN2 microplates indicate that the following substrates are utilized: L-arabinose, D-galactose, $\alpha$-D-glucose, D-mannitol, methyl pyruvate, monomethyl succinate, cis-aconitic acid, citric acid, D-galactonic acid lactone, D-galacturonic acid, D-gluconic acid, D-glucosaminic acid, D-glucuronic acid, $\beta$-hydroxybutyric acid, $\alpha$-ketoglutaric acid, DL-lactic acid, quinic acid, D-saccharic acid, succinic acid, bromosuccinic acid, L-asparagine, L-aspartic acid, L-glutamic acid, L-histidine, hydroxy-Lproline, L-proline, L-pyroglutamic acid, L-serine, $\gamma$-aminobutyric acid, urocanic acid and glycerol. Weak utilization is observed of D- and L-alanine, DL-carnitine, putrescine and 2 -aminoethanol. The other organic substrates included in the Biolog GN2 microplates are not utilized. Consistent with the chemical properties of the genus, the major respiratory lipoquinone present is ubiquinone 9 (Q9) and the major phospholipids are phosphatidylglycerol, diphosphatidylglycerol and phosphatidylethanolamine. The fatty acids present include $3-\mathrm{OH} 10: 0,12: 0,2-\mathrm{OH} 12: 0,3-\mathrm{OH} 12: 0,14: 0$, $16: 1 \omega 7 c, 16: 1 \omega 7 t, 16: 0$, cyclo $17: 0,18: 1 \omega 7 c, 18: 0$ and cyclo 19:0. The level of $14: 0$ does not exceed $1.5 \%$. The $3-\mathrm{OH} \mathrm{10:0}$ and 2-OH 12:0 are ester-linked, while the $3-\mathrm{OH}$ $12: 0$ is amide-linked.

The type strain is RW10 ${ }^{\mathrm{T}}\left(=\mathrm{DSM} 12647^{\mathrm{T}}=\right.$ CCUG $\left.53114^{\mathrm{T}}\right)$.

\section{Description of Pseudomonas mohnii sp. nov.}

Pseudomonas mohnii (moh'ni.i. N.L. gen. n. mohnii of/from Mohn, named in honour of William Mohn, for his pioneering contributions to the study of the biodegradation of resin acids).

Cells are Gram-negative and do not form spores. Colonies are circular and white-yellow on LB agar. Cells do not produce a fluorescent pigment on King's B medium. Cells are oxidase-positive and show hydrolysis of arginine, but do not reduce nitrates or hydrolyse Tween 80 . Does not show lecithinase, urease or $\beta$-galactosidase reactions or hydrolysis of aesculin or gelatin. Indole is not produced on tryptophan and there is no glucose fermentation. Does not grow at $41{ }^{\circ} \mathrm{C}$ or in media supplemented with 5 or $7 \% \mathrm{NaCl}$. Results obtained with Biolog GN2 microplates indicate that the following substrates are utilized: L-arabinose, D-galactose, $\alpha$-D-glucose, D-mannitol, methyl pyruvate, cis-aconitic acid, citric acid, D-galactonic acid lactone, D-galacturonic acid, D-gluconic acid, D-glucuronic acid, $\beta$-hydroxybutyric acid, $\alpha$-ketoglutaric acid, DL-lactic acid, quinic acid, D-saccharic acid, succinic acid, bromosuccinic acid, D-alanine, L-alanine, L-asparagine, L-aspartic acid, L-glutamic acid, hydroxy-L-proline, L-proline, L-serine, DL-carnitine, $\gamma$ aminobutyric acid, urocanic acid and glycerol. Weak utilization is observed of D-mannose, monomethyl succinate, formic acid, D-glucosaminic acid, malonic acid, propionic acid, phenylethylamine and putrescine. The other organic substrates included in the Biolog GN2 microplates are not utilized. Consistent with the chemical properties of the genus, the major respiratory lipoquinone present is ubiquinone 9 (Q9) and the major phospholipids are phosphatidylglycerol, diphosphatidylglycerol and phosphatidylethanolamine. The fatty acids present include $3-\mathrm{OH} 10: 0$, $12: 0,2-\mathrm{OH} 12: 0,3-\mathrm{OH} 12: 0,14: 0,16: 1 \omega 7 c, 16: 1 \omega 7 t$, $16: 0$, cyclo $17: 0,18: 1,18: 1 \omega 7 c$ and $18: 0$. The level of 14:0 does not exceed 1.5\%. The 3-OH 10:0 and 2-OH $12: 0$ are ester-linked, while the $3-\mathrm{OH} 12: 0$ is amide-linked.

The type strain is IpA-2 ${ }^{\mathrm{T}}\left(=\mathrm{DSM} 18327^{\mathrm{T}}=\right.$ CCUG $\left.53115^{\mathrm{T}}\right)$.

\section{Acknowledgements}

B. C. and D. H. P. wish to acknowledge funds from the DFG-European Graduate College 653. C.S. was funded by the German National Genome Sequencing Network (NGFNII). We thank A. Frühling and Bettina Sträubler (DSMZ) for excellent technical assistance. E. R. B. Moore and $\mathrm{H}$. Heuer are acknowledged for providing the 16S rRNA gene sequence of strain $\mathrm{MT}^{\mathrm{T}}$.

\section{References}

Ait Tayeb, L., Ageron, E., Grimont, F. \& Grimont, P. A. (2005). Molecular phylogeny of the genus Pseudomonas based on rpoB sequences and application for the identification of isolates. Res Microbiol 156, 763-773.

Anzai, Y., Kim, H., Park, J. Y., Wakabayashi, H. \& Oyaizu, H. (2000). Phylogenetic affiliation of the pseudomonads based on 16S rRNA sequence. Int J Syst Evol Microbiol 50, 1563-1589.

Cashion, P., Holder-Franklin, M. A., McCully, J. \& Franklin, M. (1977). A rapid method for the base ratio determination of bacterial DNA. Anal Biochem 81, 461-466.

Coenye, T. \& Vandamme, P. (2003). Intragenomic heterogeneity between multiple $16 \mathrm{~S}$ ribosomal RNA operons in sequenced bacterial genomes. FEMS Microbiol Lett 228, 45-49.

Cowan, S. T. \& Steel, K. J. (1974). Cowan and Steel's Manual for the Identification of Medical Bacteria, 2nd edn. Cambridge: Cambridge University Press.

Dorn, E., Hellwig, M., Reineke, W. \& Knackmuss, H. J. (1974). Isolation and characterization of a 3-chlorobenzoate degrading pseudomonad. Arch Microbiol 99, 61-70.

Ernst, R. K., Yi, E. C., Guo, L., Lim, K. B., Burns, J. L., Hackett, M. \& Miller, S. I. (1999). Specific lipopolysaccharide found in cystic fibrosis airway Pseudomonas aeruginosa. Science 286, 1561-1565.

Gerhardt, P., Murray, R. G. E., Wood, W. A. \& Krieg, N. R. (editors) (1994). Methods for General and Molecular Bacteriology. Washington, DC: American Society for Microbiology.

Hilario, E., Buckley, T. R. \& Young, J. (2004). Improved resolution on the phylogenetic relationships among Pseudomonas by the combined analysis of atpD, carA, recA and $16 \mathrm{~S}$ rDNA. Antonie van Leeuwenhoek 86, 51-64.

Jukes, T. H. \& Cantor, C. R. (1969). Evolution of protein molecules. In Mammalian Protein Metabolism, pp. 21-132. Edited by H. H. Munro. New York: Academic Press.

King, E. O., Ward, M. K. \& Raney, D. E. (1954). Two simple media for the demonstration of pyocyanin and fluorescein. J Lab Clin Med 44, 301-307. 
Kumar, S., Tamura, K. \& Nei, M. (2004). MEGA3: integrated software for molecular evolutionary genetics analysis and sequence alignment. Brief Bioinform 5, 150-163.

Kwon, S. W., Kim, J. S., Park, I. C., Yoon, S. H., Park, D. H., Lim, C. K. \& Go, S. J. (2003). Pseudomonas koreensis sp. nov., Pseudomonas umsongensis sp. nov. and Pseudomonas jinjuensis sp. nov., novel species from farm soils in Korea. Int J Syst Evol Microbiol 53, 21-27.

Labrenz, M., Collins, M. D., Lawson, P. A., Tindall, B. J., Braker, G. \& Hirsch, P. (1998). Antarctobacter heliothermus gen. nov., sp. nov., a budding bacterium from hypersaline and heliothermal Ekho Lake. Int J Syst Bacteriol 48, 1363-1372.

Martin, V. J., Yu, Z. \& Mohn, W. W. (1999). Recent advances in understanding resin acid biodegradation: microbial diversity and metabolism. Arch Microbiol 172, 131-138.

Mohn, W. W., Wilson, A. E., Bicho, P. \& Moore, E. R. (1999). Physiological and phylogenetic diversity of bacteria growing on resin acids. Syst Appl Microbiol 22, 68-78.

Moore, E. R. B., Mau, M., Arnscheidt, A., Böttger, E. C., Hutson, R. A., Collins, M. D., Van de Peer, Y., de Wachter, R. \& Timmis, K. N. (1996). The determination and comparison of the 16S rRNA gene sequences of species of the genus Pseudomonas (sensu stricto) and estimation of the natural intrageneric relationships. Syst Appl Microbiol 19, 478-492.

Nei, M. \& Kumar, S. (2000). Molecular Evolution and Phylogenetics. New York: Oxford University Press.

Nelson, K. E., Weinel, C., Paulsen, I. T., Dodson, R. J., Hilbert, H., Martins dos Santos, V. A., Fouts, D. E., Gill, S. R., Pop, M. \& other authors (2002). Complete genome sequence and comparative analysis of the metabolically versatile Pseudomonas putida KT2440. Environ Microbiol 4, 799-808.

Nikodem, P., Hecht, V., Schlömann, M. \& Pieper, D. H. (2003). New bacterial pathway for 4- and 5-chlorosalicylate degradation via 4-chlorocatechol and maleylacetate in Pseudomonas sp. strain MT1. J Bacteriol 185, 6790-6800.

Palleroni, N. J. (1984). Pseudomonas Migula 1894, 237 ${ }^{\mathrm{AL}}$. In Bergey's Manual of Systematic Bacteriology, vol. 1, pp. 141-199. Edited by N. R. Krieg \& J. G. Holt. Baltimore: Williams \& Wilkins.

Palleroni, N. J., Ballard, R. W., Ralston, E. \& Doudoroff, M. (1972). Deoxyribonucleic acid homologies among some Pseudomonas species. J Bacteriol 110, 1-11.

Palleroni, N. J., Kunsawa, R., Contopoulou, R. \& Doudoroff, M. (1973). Nucleic acid homologies in the genus Pseudomonas. Int J Syst Bacteriol 23, 333-339.

Pelz, O., Tesar, M., Wittich, R. M., Moore, E. R., Timmis, K. N. \& Abraham, W. R. (1999). Towards elucidation of microbial community metabolic pathways: unravelling the network of carbon sharing in a pollutant-degrading bacterial consortium by immunocapture and isotopic ratio mass spectrometry. Environ Microbiol 1, 167-174.
Pieper, D. H. \& Reineke, W. (2004). Degradation of chloroaromatics by pseudomona(d)s. In Pseudomonas, pp. 509-574. Edited by J.-L. Ramos. New York: Kluwer Academic/Plenum Publishers.

Sohlenkamp, C., Lopez-Lara, I. M. \& Geiger, O. (2003). Biosynthesis of phosphatidylcholine in bacteria. Prog Lipid Res 42, 115-162.

Stead, D. E. (1992). Grouping of plant-pathogenic and some other Pseudomonas spp. by using cellular fatty acid profiles. Int $J$ Syst Bacteriol 42, 281-295.

Thompson, J. D., Gibson, T. J., Plewniak, F., Jeanmougin, F. \& Higgins, D. G. (1997). The CLUSTAL_X windows interface: flexible strategies for multiple sequence alignment aided by quality analysis tools. Nucleic Acids Res 25, 4876-4882.

Tindall, B. J. (1990a). A comparative study of the lipid composition of Halobacterium saccharovorum from various sources. Syst Appl Microbiol 13, 128-130.

Tindall, B. J. (1990b). Lipid composition of Halobacterium lacusprofundi. FEMS Microbiol Lett 66, 199-202.

Vancanneyt, M., Witt, S., Abraham, W.-R., Kersters, K. \& Fredrickson, H. (1996). Fatty acid content in whole-cell hydrolysates and phospholipids fractions of pseudomonads: a taxonomic evaluation. Syst Appl Microbiol 19, 528-540.

Wayne, L. G., Good, R. C., Krichevsky, M. I., Blacklock, Z., David, H. L., Dawson, D., Gross, W., Hawkins, J., Levy-Frebault, V. V. \& other authors (1991). Fourth report of the cooperative, open-ended study of slowly growing mycobacteria by the International Working Group on Mycobacterial Taxonomy. Int J Syst Bacteriol 41, 463-472.

Wilkinson, S. G. (1968). Studies on the cell walls of Pseudomonas species resistant to ethylenediaminetetra-acetic acid. J Gen Microbiol 54, 195-213.

Wilson, A. E., Moore, E. R. \& Mohn, W. W. (1996). Isolation and characterization of isopimaric acid-degrading bacteria from a sequencing batch reactor. Appl Environ Microbiol 62, 3146-3151.

Wittich, R. M., Strömpl, C., Moore, E. R., Blasco, R. \& Timmis, K. N. (1999). Interaction of Sphingomonas and Pseudomonas strains in the degradation of chlorinated dibenzofurans. J Ind Microbiol Biotechnol 23, 353-358.

Yamamoto, S. \& Harayama, S. (1995). PCR amplification and direct sequencing of $g y r B$ genes with universal primers and their application to the detection and taxonomic analysis of Pseudomonas putida strains. Appl Environ Microbiol 61, 1104-1109.

Yamamoto, S., Bouvet, P. J. \& Harayama, S. (1999). Phylogenetic structures of the genus Acinetobacter based on gyrB sequences: comparison with the grouping by DNA-DNA hybridization. Int $J$ Syst Bacteriol 49, 87-95.

Yamamoto, S., Kasai, H., Arnold, D. L., Jackson, R. W., Vivian, A. \& Harayama, S. (2000). Phylogeny of the genus Pseudomonas: intrageneric structure reconstructed from the nucleotide sequences of gyrB and rpoD genes. Microbiology 146, 2385-2394. 